\title{
RECOGNITION OF A STAFF UNION OF BUSINESS AGENTS UNDER THE NATIONAL LABOR RELATIONS ACT
}

IN recent years staff employees of several unions have organized their own unions to represent them in collective bargaining, ${ }^{1}$ and these unions have been certified by the National Labor Relations Board. ${ }^{2}$ Since most employing unions have agreed to bargain with staff unions, the refusal of the Ladies' Garment Workers to bargain with a certified staff union that includes business agents ${ }^{3}$ presents a marked contrast to this trend. The struggle between the Garment Workers and the staff union, the Federation of Union Representatives, ${ }^{4}$ has been carried on in NLRB proceedings for two years, and it will probably soon reach the courts for a final decision. To the usual mutual recriminations characteristic of every labor dispute, there is added in this case the claim by each side that it represents the pure spirit of trade unionism.

1. Staff unions have been organized in the Newspaper Guild, the Airline Pilots', Teachers', Insurance Workers', Chemical Workers', Oil and Chemical Workers', Rubber Workers', Papermakers', and Electrical Workers' Unions, and in the AFL-CIO. Benson, When Organizers Organize, in RePRINTs on UnION DeMocracY in Actron No. 2 at 2. These staff unions represent organizers, business agents, international representatives, education directors, and others in administrative positions in the unions.

2. E.g., Textile Workers of America, 138 N.L.R.B. No. 30 (1962); Internationtal Ladies' Garment Workers' Union, 131 N.L.R.B. 111 (1961) ; AFL.CIO, 120 N.L.R.B. 969 (1958); Air Line Pilots Ass'n, 97 N.L.R.B. 929 (1951).

3. The business agents, who make up the largest part of the staff union's membership, are the chief source of controversy, the ILGWU having offered to recognize a unit of organizers. Brief for Respondent, p. 5, International Ladies' Garment Workers' Union, 131 N.L.R.B. 111 (1961). [Hereinafter cited as ILGWU Brief.]

4. On December 18,1960, the Federation of Union Representatives [hercinafter referred to as FOUR] petitioned the ILGWU for recognition as bargaining agent for a unit composed of business agents, organizers, and staff members doing union label, political, and educational work. Only staff members on the International's payroll (as distinguished from its locals') were included in the unit. The ILGWU's General Executive Board refused and decided to contest the staff union's certification. Responding to a petition by FOUR under $\S 9$ (c)(1)(A) of the National Labor Relations Act, the NLRB called a representation election for March 12, 1961. Ballots were contested, and FOUR was not finally certified until July 23, 1962. Since then, President Dubinsky has refused to bargain with the certified staff union. In the course of the protracted dispute FOUR brought charges of unfair labor practices against the ILGWU, alleging discharges and "coercive and discriminatory conduct". The NLRB trial examiner found that the ILGWU had committed some of the practices alleged, International Ladies' Garment Workers' Union v. Federation of Union Representatives, Cases No. 2-CA-7857-1 and 2-CA-7923, Trial Examiner's Report, and his decision is being appealed to the Board by both parties.

5. President Dubinsky argues that the ILGWU staff members have succumbed to "the commercialism of our times" and have lost the sense of the union as a mission. Appendix to ILGWU Brief, p. 5. On the other hand, FOUR says that the ILGWU has "put into jeopardy the right to union representation" of large classes of workers. FOUR folder, "LABOR DAY ! Organized Labor Marches In Dignity !" 
The National Labor Relations Act excepts from its definition of employer "any labor organization (other than when acting as an employer)." In Airline Pilots Ass'n. the NLRB, stating that a union would be treated the same as any other employer vis-a-vis its own employees, upheld the right of the union employees to organize. Four years later, in Oregon Teamsters' Security Plan Office, ${ }^{8}$ the Board, reversing this holding, declined as a matter of discretion to assert jurisdiction over labor disputes in which the employer was a union. 9 Referring to its decisions declining jurisdiction over non-profit organizations, ${ }^{10}$ the Board held that the policies of the act would not be effectuated by the assertion of jurisdiction in cases where the employer was a union. The Supreme Court disagreed, holding that, although the Board could decline to assert jurisdiction in particular cases, it could not make a wholesale exclusion of labor unions as employers in the face of the provision in the NLRA that unions should be treated as employers when they act as employers. ${ }^{11}$

The Oregon Teamsters case involved office-clerical employees. Subsequent cases have involved union employees in higher positions in the union hierarchy, but the Board has asserted jurisdiction in every case, not recognizing any instance in which the policies of the act would better be effectuated by declining jurisdiction. ${ }^{12}$

The role and function of business agents and their lack of control over the conditions of their employment bring them within the definition of employees as that term is used in the act. In general, business agents serve as a liaison between the union administration and the membership and mediate at the lowest level between the workers and the primary employer, handling grievances in the shops, policing the collective argeements, and helping to administer and service the locals. ${ }^{13}$ More responsible tasks are usually reserved for

6. National Labor Relations Act, § 2(2), 49 Stat. 450 (1935), 29 U.S.C. § 152(2) (1958). [Hereinafter cited as NLRA.]

7. 97 N.L.R.B. 929 (1951). The decision ordered separate representation elections for staff employees: one for professional employees, including attorneys, engineers, and a statistician; another for non-professional employees, including contract negotiators, the publicity man, and the Washington representative.

8. 113 N.L.R.B. 987 (1955).

9. Id. at 990 .

10. Ibid.

11. Office Employees' Int'1. Union v. NLRB, 353 U.S. 313 (1957).

12. Cases cited supra note 2.

13. ILGWU Brief, pp. 15-22. In the ILGWU's Connecticut district, for cxample, there are three business agents, all stationed in New Haven, who work under a district leader and make daily rounds in the state. They run the local meetings, but when contracts are to be negotiated, the district leader takes charge. The focus of their attention is on local matters. Interview with ILGWU Business Agent, November, 1962. Contrast the situation of the elected business agent in the building trades as described in BARBASR, LAROR's Grass Roots, ch. 5 (1961). Their greater independence from the International and their autonomous power, as contrasted to that of the ILGWU's business agents, point up the fact that "business agent" is a term of no fixed meaning. Therefore, with each petition for certification of a staff union including business agents in the unit, the Board should consider the actual duties 
the district managers. Business agents generally serve without contracts and are subject to dismissal at any time. ${ }^{14}$ The salaries of ILGWU business agents range from $\$ 65$ to $\$ 110$ per week plus fixed expenses..$^{15}$ It therefore seems clear that business agents are prey "to the evils the statute was designed to eradicate", $;^{16}$ inequality of bargaining power with its concomitant, lack of control over wages. ${ }^{17}$ Stated differently, they are as much in need of collective organization as any other class of protected employees.

Some employees, however, are denied the protection of the act because of other policy considerations, notwithstanding that these employees would benefit from collective organization. The principal policy which has led to this restriction rests on a concern for the efficient operation of the employer's business and a desire not to impair the loyalty of certain employees. The Board has implemented this policy by excluding from the protection of the act those employees "who formulate, determine, and effectuate an employer's policy."18 The organizational and collective bargaining activities of these employees are not protected, at least under federal law, against employer coercion, restraint, or interference. ${ }^{19}$

The ILGWU argues that its business agents fall within this category of managerial employees. In support, it cites the influence that business agents exert through daily contact with the rank and file and the fact that they are eligible to be delegates to the triennial International Convention. ${ }^{20}$ The influence of business agents, however, is for the most part limited to the communication of official policies formulated at higher levels of authority. The performance of their jobs leaves little opportunity for the kind of independent policy-formulation envisaged by the Board's definition. As to their eligibility to serve as convention delegates, the lack of actual choice of candidates at the ILGWU and other union conventions, ${ }^{21}$ the relative impotence of convention

performed by the business agents involved. In this Note, the term business agent will be used for those who perform functions roughly similar to those described in the text. The forty or fifty per cent of the ILGWU's business agents who are elected and paid by their locals, generally located in the large urban centers, are not involved in FOUR.

14. The business agents in the ILGWU deliver signed resignations when they begin work. Brief for Petitioner, p. 5, International Ladies' Garment Workers' Union, 131 N.L. R.B. 111 (1961). [Hereinafter cited as FOUR Brief.]

15. ILGWU Brief, p. 26. Many other unions pay their staff members more; as of 1961 the highest appeared to be was the Plumbers' Union, which paid its staff members $\$ 15,000$ per year. FOUR Newsletter, April 25, 1961.

16. NLRB v. Hearst Publications, Inc., 322 U.S. 111, 127 (1944).

17. NLRA \& 1 .

18. AFL-CIO, 120 N.L.R.B. 969, 973 (1958). And see, c.g., Ford Motor Co, 66 N.L.R.B. 1317, 1322 (1946) ; American Broadcasting Co., 107 N.L.R.B. 74, 79 (1953).

19. This is not to say that managerial employees cannot form a union. It only means that such a union is denied the protection of the act, and union-employer relations are left to be settled by economic force.

20. ILGWU Brief, pp. 37-39.

21. In a study of thirty-four unions between 1900 and 1948, Philip Taft found that of 2,307 elections of general officers, only 537 were contested. Of 254 elections in the ILGWU, 53 have been contested; and no general offices in the ILGWU were contested from 1937 to 1954. TAFT, The Structure and Governasent of LABOR UnIons 38-39, 46 (1954). 
actions, ${ }^{22}$ and the small number of business agents actually chosen as delegates ${ }^{23}$ indicate that the effect on the employing union's policy and administration of any conflict of interest on the part of the business agents in serving as convention delegates would be minimal. ${ }^{24}$

In resolving the conflict between the policy of encouraging collective bargaining and that of minimizing certain interferences with an employer's business operations, Congress has excluded another category of employees. Responding to opposition generated by a Supreme Court decision holding that foremen were employees, ${ }^{25}$ Congress provided in Taft-Hartley that supervisors were beyond the purview of the NLRB. A supervisor is defined as "any individual having authority, in the interest of the employer, to hire, transfer, suspend. . . or discipline other employees, or responsibly to direct them. . . ."20 This provision, however, has no direct application to business agents, for the definition is written wholly in terms of authority over other employees. Business agents, on the lowest level of union bureaucracy, have no such authority. Arguably, however, the policy underlying this provision reaches business agents as well as foremen. Foremen are denied the right to organize in order to insure that the employer's interests will be faithfully represented in the shop. And if management's representatives to labor cannot organize under the act, labor's representatives to management-the business agents-should not be

22. In most instances the union convention is an expertly managed affair designed to give the delegates, and through them the membership, a sense of the union's importance... The convention provides an opportunity for a fev men from each local to have what approximates a good time at the union's expense. ... When dissension does come out in convention session, it may not be unusual for somebody to wealien the dissenter's position by saying that the open criticism of the union's policies can only give "aid and comfort" to the employers.

Barbash, The Practice of Unionisar, 60-61 (1956).

Conventions do, of course, present an opportunity for resolving differences, holding Id. at 61-62.

officers to account, and, occasionally, for openly debating union policies.

23. At the ILGWU's 1959 convention, no more than thirteen of approximately 960 delegates were members of the bargaining unit represented by FOUR. FOUR Brief, p. 14.

24. In the analogous situation of employees who hold stock in the employer corporation, the Board has held that an insignificant interest should not exclude an cmployee from a rank and file union. A stockholder employee should be excluded only if he has "an effective voice in the formulation and determination of corporate policy." Alderwood Products Corp., 81 N.L.R.B. 136, 138 (1949). A similar test should be applied to business agents. If the employing union is anxious about the effects of even this small conflict of interest, it could probably make business agents ineligible to serve as convention delegates. While the Labor-Management Reporting and Disclosure Act of 1959 (Landrum-Grifin Act), § 101(a) (1), 73 Stat. 519 (1959), 29 U.S.C. \& 411 (Supp. II 1959) [hereinafter cited as Landrum-Grifin] guarantees equal rights and privileges to every union member, the guarantee is subject to "reasonable rules and regulations." Making business agents ineligible to serve as convention delegates seems to be a reasonable regulation.

25. ' Packard Motor Co. v. NLRB, 330 U.S. 485 (1947).

26. Iabor-Management Relations Act (Taft-Hartley Act), § 101, 61 Stat. 137 (1947), 29 U.S.C. § 152(11) (1958) (emphasis added). [Hereinafter cited as LARRA.] 
permitted to organize either. ${ }^{27}$ However appealing aesthetically, the argument is founded on the questionable assumption that organization for collective bargaining is, in every case, incompatible with loyal and effective representation of the employer. In excluding supervisors from the coverage of the act, Congress was not framing a general postulate of this sort to serve as a major premise for deciding subsequent cases. They had before them empirical evidence that the organization of foremen led to the growth of a sympathetic tie between foremen and the plant unions, and a consequent decline of loyalty to management. ${ }^{28}$ The foreman's job requires him to deal with the employees' union in an adverse capacity; therefore, any growth of sympathy for the union would mean a corresponding decline in loyalty to the employer. Also, the success of any foremen's union would depend on retaining the sympathy of the rank and file union, creating an obvious conflict of interests. These considerations would not be present with a union of business agents; although their union would give them some independence of the employing union, no similar reason appears for a decline in their loyalty in representing the union's interest. Unlike the case with unionized foremen, sympathy for fellow* employees, the members of the employing union, would lead the business agents to do a better job of representing. And there is no community of interest between the staff union and the primary employer.

Therefore since business agents are employees in the sense that they are as much in need of the protection of the act as other employees, and since they do not come under the Board's definition of managerial employees or the act's definition of supervisors, the Board seems correct in concluding that business agents are within the coverage of the NLRA. Since staff employees fulfill an important role in the union's internal structure, however, recognition of a staff union poses considerations not present where ordinary employees are recognized and afforded the benefits of the NLRA. For this reason, the Board, in deciding whether to exercise its discretion to decline jurisdiction, ${ }^{20}$ should consider the

27. ILGWU Brief, p. 45. There is material in the legislative history of the TaftHartley Act that gives some weight to this argument. E.g.: "Management, like labor, minst have faithful agents." 1 Legislative History of the Labor Management Relations ACT 307 (1948). [Hereinafter cited as LeG. HIST. of LMRA]. See also id. at 304-08, 409-11. This delusive sense of symmetry underlies an offer by Representative Griffin to President Dubinsky to sponsor an amendment to Taft-Hartley exempting business agents from the employee class should the ILGWU lose its court battle. Justice, Oct. 1, 1962, p. 8, col. 4.

28. The House Committee on Education and Labor reported:

The evidence shows that foremen's unions are, and must be, wholly dependent upon rank-and-file unions and under constant obligation to them. The foremen cannot strike without the support of the rank and file and its agreement not to do the work of striking foremen.

1 LEG. HIST. of LMRA 306-07. The committee found on the basis of much testimony that the foremen's unions developed "at the expense of the foreman's fidelity in doing his dutics." Ibid.

29. The range of certification cases in which the Board has considered the possibility of exercising its discretion is quite narrow; it does not appear that the Board considered this question in passing on FOUR's petition. That the Board ought to have considered this question is indicated by the Supreme Court's opinion in Office Employees' Int'l Union v. 
probable effects of staff union recognition in the light of the general policies expressed in the national labor legislation ${ }^{30}$ as well as the policies underlying the exclusion of supervisors and managerial employees from the coverage of the act. The latter considerations go to the question whether jurisdiction can, not should, be exercised.

The principal policy of the National Labor Relations Act is to foster collective organization and establish conditions under which unions can effectively represent and pursue the interests of the employees in the bargaining unit. ${ }^{31}$ But the

NLRB, 353 U.S. 313 (1957). There, while it reversed the Board's rule declining jurisdiction over labor unions as employers, the Court recognized that the Board could properly decline to assert jurisdiction if " the policies of the Act would not be effectuated by its assertion of jurisdiction in that case," id. at 318, quoting Labor Board v. Denver Bldg. Council, 341 U.S. 675, 684 (1951). Four Justices, dissenting in part, argued that the Board did have discretionary authority to exclude union employers as a class from the coverage of the act. Finding the Board's reasoning unconvincing, however, they urged remand for reconsideration. Under either view, the Board, in deciding whether to exercise its jurisdiction, should consider the probable effects of staff union recognition in the light of the policies expressed in the national labor legislation.

30. NLRA § 14(c) (1), an amendment added by Landrum-Griffin, explicitly confers discretion on the Board with a proviso:

The Board, in its discretion, may ... decline to assert jurisdietion over any labor dispute involving any class or category of employers, where in the opinion of the Board, the effect of such labor dispute on commerce is not sufficiently substantial to warrant the exercise of its jurisdiction: Provided; That the Board shall not decline to assert jurisdiction over any labor dispute over which it would assert jurisdiction under the standards prevailing upon August 1, 1959.

The proviso has been interpreted in Leedom v. Fitch Sanitarium, Inc, 294 F.2d 251 (D.C. Cir. 1961), where the court upheld the NLRB's refusal to assert jurisdiction over a petition for a representation election filed by a proprietary hospital. The Court said that the Board could refuse to assert jurisdiction "unless prior to August 1, 1959 the Board had established a jurisdictional standard affirmatively including such institutions." Id. at 255. The fact that the Board had taken jurisdiction of occasional disputes before 1959 does not establish a "prevailing standard" under this section. Thus the scattered decisions of the Board prior to August, 1959 asserting jurisdiction over staff unions do not limit the Board's discretion.

The grant of discretion in NLRA § 14(c) (1) should not be read as limiting the Board's discretion to situations in which the effect of the dispute on commerce is insubstantial. The Board has properly continued to decline jurisdiction where the policies of the NLRA would not be effectuated by assertion for other reasons. In Sheltered Workshops of San Diego, 126 N.L.R.B. 961,964 (1960), the Board declined jurisdiction over a nonprofit enterprise on the basis of the policies of the act, without considering in detail the substantiality of the effect on commerce. Clearly, the Board should have authority to decline jurisdiction in a case where assertion would frustrate the act's purposes. For example, in Hamilton Bros., 133 N.L.R.B. 868, 871 (1961), the Board properly considered the policies of the act in deciding whether to assert jurisdiction over flag-of-convenience labor disputes. There are, however, statements which might be construed as meaning that the Board considered its discretion limited to a consideration of the effect on commerce. E.g., 26 NLRB Axn. REP. 22 (1961) ; West India Fruit \& S.S. Co., 130 N.L.R.B. 343, 370-71 (1961).

31. Experience has proved that protection by law of the right of employees to organize and bargain collectively safeguards commerce from injury, impairment, or interruption, and promotes the flow of commerce by removing certain recognized sources ... of industrial strife and unrest and by restoring equality of bargaining power betweeri employers and employees....

NLRA § 1. 
act also recognizes that a union has certain obligations to its own employees when it acts as an employer. ${ }^{32}$ Cases may arise where the question whether the Board should assert jurisdiction over staff unions will necessitate a preference for one of these two policies. Exercising jurisdiction over the collective activities of business agents, however, does not appear to pose such a conflict.

Recognition of a union representing business agents could impair the employing union's effective representation of the rank and file either by curtailing the employing union's power freely to fire business agents, if the staff union obtained a good cause provision, ${ }^{33}$ or by disrupting the union's operation through a strike. As to most functions of business agents, such as policing the collective agreement and servicing the locals, the inclusion of a good cause provision in a collective agreement would not substantially undermine the efficiency with which they are performed. Although the increase in job secturity flowing from a good cause provision might make business agents somewhat less diligent in the performance of these tasks, this loss should be offset by an improvement in morale.

The effect of a good cause provision may, however, be more pronounced on the business agents' function as liaison between the administration and the rank and file. The business agents relay reports of the rank and file's problems and dissatisfactions to the administration and also inform the members of administration policies and proposals. There is no reason to expect a significant loss of efficiency in communications to the administration, but the downstream reporting of administration proposals may no longer be as satisfactory, at least to the incumbent administration. Of principal significance in this function is the willingness of business agents to present administration proposals in a favorable light. Even if a failure to report administration proposals with zeal were thought to be good cause for dismissal, such a cause for dismissal would be difficult to prove. This loss in enthusiastic presentation of the administration's proposals and edicts could be somewhat offset by the use of other channels of communication, such as the union newspaper or the elected local officers.

The possibility of a strike of the staff union may be thought to present a more serious threat to the efficiency of the employing union. Because of the limited resources and power of a staff union, at least in its early stages, how ever, strikes, especially protracted ones, are not very likely. Moreover, business

32. "The term 'employer' ... shall not include ... any labor organization (other than when acting as an employer)...." NLRA \& 2(2).

33. A staff union should be able to get a dismissal for a good cause provision in their collective agreement. Such a clause has become standard in union contracts, and the cmploying union would be unlikely to contest a matter so fundamental to unions. Of the 400 collective agreements studied in a 1960 survey conducted by the Bureau of National Affairs $71 \%$ of them contained some kind of good cause provision. 46 LRRM 23-24.

A good cause provision would not, of course, entirely insulate the business agent from improper administration pressures. By the use of discriminatory transfers and other measures, the administration could still exert a large measure of control over the business agents. But the good cause provision does give them considerable independence. 
agents might be reluctant to strike since they can be readily replaced by local officers or other members of the employing union. Presumably these members would consider performing the business agents' function as something other than strike-breaking, since their action would be authorized by their elected leaders and would serve the interests of their own union. Because the replacements would initially not be completely familiar with the tasks performed by business agents, some delays in processing grievances and in enforcing the collection agreement may be expected. But such delays are likely to be short since the skills of a business agent can be readily acquired.

In concluding that recognition of a staff union would probably not signifcantly impair the efficiency of the employing union, no consideration so far has been given to the business agents' political function. It is in this area, which concerns the internal political processes of the employing union rather than the fulfillment of its responsibility as bargaining representative, that recognition of staff unions would probably have its most significant impact. The real authority for decision-making and policy-formulation in today's unions clearly lies in the administration. ${ }^{34}$ With the aid of an efficient bureaucracy, the incumbent officers have substantially restricted the opportunity for voicing opposing views. Notwithstanding the preservation of democratic forms ${ }^{35}$ the administration is often not responsive to the opinions and desires of the members. ${ }^{36}$ Protest by members of the rank and file is regarded as dis-

34. Lipset, Trow \& Colearan, Unrox Dexrocracy ch. 1 (1956) ; Herberg, Burcaucracy and Democracy in Labor Unions, in Shister, Readings in Labor Econouncs arid Industrial Relations 114 (1956); Seidman, Democracy in Labor Unions, in Shister, op. cit. supra at 122.

35. A graphic example of the preservation of the democratic form without the substance is contained in the ILGWU constitution, art. $8, \S 6$. This section permits caucuses of members but only for the three month period before an election. As has been pointed out, this provision cripples any organized opposition to the administration. Sce Lrpser, Trow \& Colemian, op. cit. supra note 33, at 239-40. See also LeIserson, Aurerican Trade Umion DEMOCRACY 233-34 (1959). The ILGWU art. 8, \& 6 was enacted in the wake of the struggle with the Communists in the union in order to avoid self-destructive dual-unionism, but it has outlived that purpose. For example, a caucus organized to protest the termination of the Yiddish edition of Justice was broken up under this article of the constitution. Benson, When Organizers Organize, in Reprints on UnIon Desrocracy in Acroos No. 2, at 2.

36. Most large unions... approximate the state of the masses in their lack of mediating organizations between the administration and the individual members. The average large trade union contains only one formal organization, the union apparatus itself, and a mass of individual members.... It is perhaps paradoxical that the very organizations which allow workers to act collectively in their relations with employers are ordinarily so constructed that within them the members are usually unable to act collectively in dealing with their leaders.

LIPSET, TROW \& COLEMAN, op. cit. supra note 33, at 77. An absence of membership control over policy formulation is suggested by the charitable donations of the ILGWU. Although the size of the contribution is itself admirable, the distribution shows little regard for the needs and interests of a large part of the membership. See Jacobs, David Dubinsky: Why His Throne is Wobbling, Harper's Magazine, Dec. 1962, p. 75, at 84. 
loyalty, ${ }^{37}$ and organized opposition is discredited as factionalism or dual unionism. . $^{38}$

The business agents play an essential role in maintaining these decisionmaking prerogatives of the administration by informal pressures at the local level, where their advocacy carries great weight. They urge loyalty to the administration and its program, campaign for the incumbents, and seek to head off factional challenges. In the absence of a staff union, the business agent holds his job at the will of the employing union, a situation which insures the diligent pursuit of the business agents' political tasks. Combined with the administration's practical monopoly over communication, this political machine makes opposition virtually impossible. A complete evaluation of the consequences of recognizing a staff union requires consideration of these internal political processes. And this, in turn, suggests that the NLRB, in deciding whether to decline jurisdiction over a staff union, should look to the LandrumGriffin Act, which expresses a national policy of encouraging union democracy. ${ }^{30}$

Since the effective performance of political functions by the business agent on behalf of the administration tends to frustrate the legislative policy in favor of

37. The notion that internal political conflict may be more than an unpleasant interlude in the course of an otherwise stable and settled organizational history, the idea that political conflict may itself have value for the organization within which it is waged and that the conditions under which it may flourish ought to be created and preserved-these sentiments and values, which lie at the heart of Western parliamentary democratic theory, are not widely held in such organizations as trade unions.

LIPSET, Trow \& ColeMAN, op. cit. supra note 33, at 241 .

38. The debate with FOUR has been carried on by the ILGWU administration in this rhetorical style. President Dubinsky has asked: "Shall we permit Troskyite factionalism in our union?" N.Y. Times, May 31, 1962, p. 18, col. 3. The ILGWU newspaper, Justice, in an editorial "To Set the Record Straight," wrote that FOUR "is a faction of officers with all the elements of a dual union...." It cites the union's "long and bitter experiences" with a Communist faction in justifying its actions against FOUR. Justice, Aug. 1, 1962, p. 12. Lipset, Trow \& Coleman cite the ILGWU as "a notable and clear example" of the corrclation of the fight against a Communist faction and the destruction of internal democracy. LIrSEr, Trow \& Colensan, op. cit. supra note 33, at 248.

39. See H. R. Rep. No. 741, 86th Cong., 1st Sess. 7 (1959), in 1 Legrsuatrve Hrstouy of the Labor-ManageMrent Reporting and Disclosure Act of 1959, at 765 (1959) :

[I]t is essential that union practices and procedures be democratic and that they recognize and protect the basic rights of the union members and the employees reprcsented by unions.

Senator McClellan made the same point, in submitting his Bill of Rights :

... I deem it appropriate that we insure by law internal democracy in unions and provide for proper protection of union members and their rights. ... If unions are to have such federally bestowed, tremendous power in industrial government, they should be compelled by law to represent their members in accordance with democratic principles.

2 LegisLATIVE HistoRY of LMRDA of 1959, at 1098 (1959). Given this declared legislative policy in favor of union democracy, a consideration of the wisdom or practicability of such policy is beyond the scope of this Note. For an incisive discussion of these problems, sce generally LIPSET, Trow \& ColeMran, op. cit. stipra note 33. 
union democracy, relaxation of the control of the incumbents over the political activity of the business agents would seem desirable. ${ }^{10}$ There are several ways in which recognition, and therefore protection of the organizational and collective activities of business agents, might provide an impetus to more democratic practices in the employing union. If the parties agreed to an open-ended good cause provision, which left the specific content of the provision to be filled in by the arbitrator, the arbitrator would be free to draw on the policy of the Landrum-Griffin Act in construing the collective agreement. Section 401 (g) of Landrum-Griffin provides that "no moneys received by any labor organization ... shall be ... applied to promote the candidacy of any person in an election ...."41 This section clearly applies to a business agent's political activity in campaigning for incumbents during the period immediately preceding election and may apply to other forms of union political activities. In addition, the overall intent of title IV of Landrum-Griffin is to equalize opportunities for elective office in the union, eliminating the gross advantages possessed by the incumbents. Thus, relying on this policy of Landrum-Griffin, arbitrators would probably decide that failure by a business agent to perform the political function is not good cause for dismissal. Such a decision might also impair the business agent's performance of his function of communicating administration policy to the rank and file, since a line between favorable reporting and campaigning would be virtually impossible to draw. But, as noted above, this function can be accomplished in other ways. ${ }^{42}$ If the employing union, foreseeing the consequences of a general good cause provision or reacting to reinstatements of persons dismissed for political reasons, obtained a specific provision permitting dismissal of business agents for failure to perform a political function, such a provision would probably be denied enforcement in a reinstatement proceeding on the ground that it contravenes the policy of Landrum-Griffin.

Although union democracy may be advanced by freeing the business agents from coerced political activity, it is not clear that protecting business agents in carrying on voluntary political activities would be similarly beneficial or in accord with any national policy. ${ }^{43}$ Owing to their daily grass-roots contact with

40. Section 501(a) of the Landrum-Griffin Act, imposing a fidiciary responsibility on business agents, does not impair their right to organize. This section is grounded on the common law concept of fiduciary duty which prohibits a fiduciary from representing an adverse interest in the same transaction. This section certainly does not proscribe an agent's sceling a salary increase, a dealing in which he treats the union as an adverse party; and organization for collective bargaining does not make the business agent's interest more adverse. See Cox, Internal Affairs of Labor Unions Under the Labor Reform Act of 1959, $58 \mathrm{Mircm}$. L. Rev. 819, 827-29 (1960).

41. Section $401(\mathrm{~g}), 73$ Stat. 533 (1959), 29 U.S.C. § 481(g) (Supp. II 1959).

42. See text beginning at note 32 supra.

43. The Council of Industrial Organizers, the bargaining representative of the staff members of the International Union of Electrical, Radio, and Mrachine Workers, has played an active role in IUE affairs, apparently with salutary effects. The job security which they won has enabled them to avoid compelled participation in the internal political struggle within the employing union. Individual staff members have taken independent positions without reprisals, and the staff union itself has taken positions on the issues without siding 
the rank and file, business agents have an extraordinary amount of political influence. To the extent that this influence is exerted to affect the outcome of elections, an undemocratic element of another sort is introduced into the employing union's internal structure. Business agents often are not elected by the rank and file. Moreover, their interests do not necessarily coincide with the interests of the employing union's membership. And by using their concerted political support as leverage for an especially favorable agreement, business agents may gain an advantage in collective bargaining that does not result from economic strength.

These considerations suggest that voluntary political activities of business agents should be inhibited. This could be accomplished by construing dismissals for this form of political activity as within the scope of good cause. Section $401(\mathrm{~g})$, which proscribes the use of union funds to support the candidacy of any person, ${ }^{44}$ supports this conclusion, although it may not apply to all forms of voluntary political activity by business agents. It is unrealistic, however, to expect that all voluntary political activity could be eliminated. The practical effect of construing a good cause provision to permit the dismissal of business agents for individual political activity would more likely be the dismissal of only those business agents who opposed the administration, thus giving the administration a net political advantage. Although this may be preferable to the present situation in which the incumbents command total support, it seems less desirable than permitting the business agents to engage freely in individual political activity. In the latter case, support for the administration by some business agents would be offset by the opposition of others. Furthermore, individual voluntary political activity, by stimulating discussion of current union problems, might have a salutary effect on union democracy. This leads to the conclusion that a dismissal for individual political activity should not be deemed a dismissal for good cause. Similarly, if the employing union obtained a specific provision permitting dismissals for voluntary political activity, such a provision should be construed strictly against the employing union in order to minimize the opportunity to gain the political support of the business agents by using selective dismissals. This construction would also decrease the possibility that such a provision would be abused by an employing union's casting all dismissals in the guise of dismissals for voluntary political activity.

The potential adverse effects of concerted political activity by a staff union on the union democratic process appear more serious. But the formulation of effective remedies to regulate this activity presents less of a problem. Where the staff union engages in such activity, the NLRB could suspend the bargain-

with either faction. Six staff members were fired recently, but this apparently was becausc they refused, in violation of the IUE constitution, to obey President James Carcy, and not simply because of their anti-Carey political activities. Letter from Angelo Colella, President of the Council of Industrial Organizers, to the Yale Law Journal, Dec. 24, 1962, on file in Yale Law Library ; Telephone Interview with Mr. Colella, March 3, 1963.

44. See text at note 40 supra. 
ing privileges of the staff union for a limited period of time. ${ }^{45}$ It probably could not, however, enjoin such activity as an unfair labor practice. 10 But the first remedy is preferable to the Board's declining jurisdiction absolutely, for that would only insure the perpetuation of the marked advantages of incumbency. Where the staff union opposes the incumbent administration, the employing union presumably will file an appropriate complaint with the NLRB. Even if the staff union is supporting the administration, the number of people who might benefit by Board intervention-including dissident members of the two unions involved-ensures that a complaint will be filed. The definition of the nature and intensity of concerted political activity that would justify Board intervention can be worked out in practice. A decision to decertify would probably be based upon such factors as whether the staff union has taken a position on candidates rather than issues, whether it has taken a position in its official capacity, whether it has an immediate interest in the issues on which the position has been taken, and the extent of the harm which the employing union would suffer by virtue of the particular activity involved.

In view of the fact that recognition of the staff union would afford substantial benefits to the business agents individually, would not significantly impair the efficiency of the employing union, and, most important, would have a beneficial effect on the employing union's political structure-thereby implementing the policy of Landrum-Griffin-it would seem that the Board should not exercise its discretion to decline jurisdiction.

45. The Board has asserted its authority to revoke the certification of unions in appropriate cases, whether or not the union has engaged in an unfair labor practice. See Hughes Tool Co., 104 N.L.R.B. 318, 322-24 (1953) ; Hughes Tool Co., Cases No. 23-CB429 \& 23 RC-1758, Trial Examiner's Report. In A. O. Smith Corp., 119 N.L.R.B. 621, the Board revoked a union's certification for six months for failing to fairly represent all the members of the bargaining unit. This sanction would effectively prevent a staff union from excessively interferring in the internal affairs of the employing union.

46. Arguably, such concerted political activity might be a violation of NLRA $\S 8(b)$ (1) (B), which prohibits restraining or coercing "an employer in the selection of his representatives ...." If this interpretation seemed too strained and a substantial problem developed due to staff union interference in employing unions, an amendment to the NLRA making such activity an unfair labor practice could be sought. This provision would be the analogue of NLRA $\$ 8(\mathrm{a})(2)$, which prevents interference by the employer in the union's affairs. 